\title{
An Inventory Model for Maximum Life Time Products under the Price and Stock Dependent Demand Rate
}

\author{
Vikram Vashisth \\ Department of \\ Computer Science \\ B.K. Birla Institute of \\ Engineering \\ \&Technology Pilani, \\ Rajasthan (India)
}

\author{
Ajay Tomar \\ Department of MCA \\ B.K. Birla Institute of \\ Engineering \\ \&Technology Pilani, \\ Rajasthan (India)
}

\author{
Ramakant Soni \\ Department of \\ Computer Science \\ B.K. Birla Institute of \\ Engineering \\ \&Technology Pilani, \\ Rajasthan (India)
}

\author{
A.K. Malik \\ Department of \\ Mathematics \\ B.K. Birla Institute of \\ Engineering \\ \&Technology Pilani, \\ Rajasthan (India)
}

\begin{abstract}
Today's due to competitive business scenarios, the suppliers provide his/her retailers a discount in price of a product. To attract the customers to buy more products at one time, the retailer managed the demand rate depends on price and stock dependent which is very realistic in day to day life. The holding cost is assumed to be variable. For this we proposed a model to solve such types of problems to determine the optimal replenishment policy for non-instantaneous deteriorating products. Numerical example is provided to demonstrate the optimal total profit for discussed inventory model.
\end{abstract}

\section{Keywords}

Inventory, Non-instantaneous deterioration, Variable holding cost, price and Stock-dependent demand.

\section{INTRODUCTION}

In supermarkets, stores, malls, all of the customers not only focuses on the amount of stock but also observes the price of the items. The product in a large quantity and price discount in the supermarkets attracts many customers and generates the high demand. Therefore the effect of price and stock dependent demand rate cannot be ignored for determining the optimal order policy. Levin et al. (1972) discussed the big amount of consumer goods displayed in a supermarket would attract the customer to buy more products. Gupta and Vrat (1986) first proposed an inventory model for utilization environment to optimize the total inventory cost and considering the stockdependent demand. Baker and Urban (1988) discussed an inventory model for a power-form inventory-level-dependent demand pattern. Datta and Pal (1990) gave a note on an inventory model with inventory level dependent demand rate.

Pal et al. (1993) extended the inventory model of Baker and Urban (1988) for perishable products that deteriorate at a constant rate. Bar-Lev et al. (1994) developed an extension of the inventory-level-dependent demand-type EOQ model. Padmanabhan and Vrat (1995) proposed an inventory model of deteriorating items with stock-dependent demand. Urban and Baker (1997) discussed the EOQ model in which the demand is a multivariate function of price, time, and level of inventory. Datta and Paul (2001) analyzed a multi-period EOQ model with stock-dependent and price-sensitive demand rate.

Other researchers related to this area such as Mandal and Phaujdar (1989), Giri et al. (1996 and 1998), Ray et al. (1998), etc. Chang (2004) developed an Inventory model with stockdependent demand and nonlinear holding costs for deteriorating items. Soni and Shah (2008) developed the optimal ordering policy inventory model and stock-dependent demand under the progressive payment scheme environment. Goyal and Chang
(2009) developed an inventory model with optimal ordering policy under the stock dependent demand rate.

Chang et al. (2010) discussed an optimal replenishment policy inventory model for non-instantaneous deteriorating items with stock-dependent demand rate. Lots of research work has been done in the area of inventory system with stockdependent/multivariate demand rate. One may refer to the research work of Dye and Ouyang (2005), Alfares (2007), Singh et al. (2011a, b), Malik and Kumar (2011), Singh and Malik (2011), Sana (2011), Malik and Sharma (11), Sarkar (2012), Sarkar and Sarkar (2013).Sana, S.S., (2010) proposed an inventory model for perishable items under stock-dependent demand rate. Sharma et al. (2013) developed a noninstantaneous deterioration inventory model with inflation and stock-dependent demand. Gupta et al. (2013) proposed an optimal ordering policy for stock-dependent demand inventory model with non-instantaneous deteriorating items.

This paper deals with an inventory model with price and stock dependent demand rate under the variable holding cost. The optimal replenishment policy for non-instantaneous deteriorating items with maximum life time is discussed in this proposed model. The optimizing conditions of the existence and uniqueness of the optimal solutions are given. Here investigate the possible effects of a temporary price discount offered by a supplier on a retailer's replenishment policy for deteriorating items with linear and stock dependent demand rate.

\section{NOTATION AND ASSUMPTIONS}

Proposed inventory model used the following notations and assumptions:

- The demand rate is $D(t)=a+b t+c I(t)-d p$, Where $a, b, c, d, p$ are positive constants and $\mathrm{I}(\mathrm{t})$ is the inventory level at time $t$.

- Shortages are not acceptable and lead time is zero.

- $\theta(t)=\frac{1}{1+R-t}$ is the deterioration rate

- $\mathrm{R}$ is the maximum life time of an items

- $\mathrm{A}$ is the ordering cost per order

- $h(t)=h_{1}+h_{2} t$ is the inventory holding cost per unit time

- $\mathrm{C}_{\mathrm{d}}$ is the deteriorating cost per unit

- $\mathrm{C}_{\mathrm{p}}$ is the purchasing cost per unit 
- $\quad \mathrm{p}$ is the sales revenue cost per unit

- $\mathrm{I}_{1}$ is the inventory level at time $\left[0, \mathrm{t}_{1}\right]$ in which the product has no deterioration.

- $\mathrm{I}_{2}$ is the inventory level at time $\left[\mathrm{t}_{1}, \mathrm{~T}\right]$ in which due to demand and deterioration level go to zero level.

- $\mathrm{t}_{1}$ is the time period in which product maintain their freshness.

- $t_{2}$ is the length in which occurrence of deterioration in product.

- $\quad$ TPF is the total profit function per unit time of the developed inventory system.

\section{MATHEMATICAL MODEL}

In the proposed inventory model, the time interval $[0, \mathrm{t} 1]$, the inventory level (I1) decreases due to price and stock dependent demand rate. The inventory level (I2) drops to zero due to demand and the deterioration in the items during the interval is $[\mathrm{t} 1, \mathrm{~T}]$. Therefore the inventory level in the proposed model at any time $\mathrm{t}$ can be represented by the following differential equations:

$$
\frac{d I_{1}(t)}{d t}=-\left(a+b t+c I_{1}(t)-d p\right)
$$

\section{$0 \leq \mathrm{t} \leq \mathrm{t} 1$}

$\frac{d I_{2}(t)}{d t}+\theta(t) I_{2}(t)=-\left(a+b t+c I_{2}(t)-d p\right)$

$\mathrm{t} 1 \leq \mathrm{t} \leq \mathrm{T}$

with the boundary conditions $I_{1}(0)=Q, \quad I_{2}(T)=0$ respectively, solving above equations (1) and (2), we get

$I_{1}(t)=Q e^{-c t}-n_{3}\left(e^{-c t}-1\right)-\frac{b}{c} t$

$I_{2}(t)=\left\{\begin{array}{l}\frac{b c}{2}\left(t^{2}-T^{2}\right)+n_{1}(t-T) \\ +n_{2} \log \left(\frac{1+R-t}{1+R-T}\right)\end{array}\right\} e^{-c t}(1+R-t)$

Considering continuity of $\mathrm{I}(\mathrm{t})$ at $\mathrm{t}=\mathrm{t} 1$, it follows from Eqns (3) and (4) that $I_{1}\left(t_{1}\right)=I_{2}\left(t_{1}\right)$

$$
\begin{aligned}
Q=n_{3}\left(1-e^{c t_{1}}\right)-\frac{b}{c} t_{1} e^{c t_{1}} \\
+\left\{\begin{array}{l}
\frac{b c}{2}\left(t_{1}{ }^{2}-T^{2}\right)+n_{1}\left(t_{1}-T\right) \\
+n_{2} \log \left(\frac{1+R-t_{1}}{1+R-T}\right)
\end{array}\right\}\left(1+R-t_{1}\right)
\end{aligned}
$$

Total profit per cycle contains the following components:

1) The ordering cost $(\mathrm{OC})$ is $=\mathrm{A}$.

2) The holding cost (HC) is

$$
\begin{aligned}
& H C=\left(h_{1}+h_{2} t\right)\left(\int_{0}^{t_{1}} I_{1}(t) d t+\int_{t_{1}}^{T} I_{2}(t) d t\right) \\
& =h_{1}\left[\frac{Q}{c}\left(1-e^{-c t_{1}}\right)-\frac{n_{3}}{c}\left(1-c t_{1}-e^{-c t_{1}}\right)-\frac{b}{2 c} t_{1}^{2}\right]
\end{aligned}
$$

$$
\begin{aligned}
& +h_{2}\left[\frac{Q+n_{3}}{c^{2}}\left(1-\left(c t_{1}+1\right) e^{-c t_{1}}\right)-\frac{n_{3}}{2} t_{1}^{2}-\frac{b}{3 c} t_{1}^{3}\right] \\
& {\left[\frac{m_{1}}{2}\left(T^{2}-t_{1}^{2}\right)+\frac{m_{2}}{3}\left(T^{3}-t_{1}^{3}\right)\right.} \\
& +\frac{m_{3}}{4}\left(T^{4}-t_{1}^{4}\right)+\frac{m_{4}}{5}\left(T^{5}-t_{1}^{5}\right) \\
& \left(\log (1+R-T)\left\{(1+R) T-\frac{R_{1}}{2} T^{2}+\frac{c}{3} T^{3}\right\}\right. \\
& +h_{1}\left(n_{2}\left(\begin{array}{l}
-\log \left(1+R-t_{1}\right)\left\{(1+R) t_{1}-\frac{R_{1}}{2} t_{1}^{2}+\frac{c}{3} t_{1}^{3}\right\} \\
-\frac{c}{9}\left(T^{3}-t_{1}^{3}\right)-\frac{m_{5}}{2}\left(T^{2}-t_{1}^{2}\right)-m_{6}\left(T-t_{1}\right) \\
-m_{7} \log \left(\frac{1+R-T}{1+R-t_{1}}\right)
\end{array}\right\}\right. \\
& +\left\{\frac{b c}{2} T^{2}+n_{1} T+n_{2} \log (1+R-T)\right\} \times \\
& \left.\left\{(1+R)\left(T-t_{1}\right)-\frac{R_{1}}{2}\left(T^{2}-t_{1}^{2}\right)+\frac{c}{3}\left(T^{3}-t_{1}^{3}\right)\right\}\right]
\end{aligned}
$$

$$
\begin{aligned}
& \frac{m_{1}}{3}\left(T^{3}-t_{1}^{3}\right)+\frac{m_{2}}{4}\left(T^{4}-t_{1}^{4}\right) \\
& +\frac{m_{3}}{5}\left(T^{5}-t_{1}^{5}\right)+\frac{m_{4}}{6}\left(T^{6}-t_{1}^{6}\right) \\
& \left\{\log (1+R-T)\left\{\frac{(1+R)}{2} T^{2}-\frac{R_{1}}{3} T^{3}+\frac{c}{4} T^{4}\right\}\right. \\
& +h_{2}\left(n_{2}\left(\begin{array}{l}
-\log \left(1+R-t_{1}\right)\left\{\frac{(1+R)}{2} t_{1}^{2}-\frac{R_{1}}{3} t_{1}^{3}+\frac{c}{4} t_{1}^{4}\right\} \\
-\frac{c}{16}\left(T^{4}-t_{1}^{4}\right)-\frac{m_{8}}{3}\left(T^{3}-t_{1}^{3}\right)-\frac{m_{9}}{2}\left(T^{2}-t_{1}^{2}\right) \\
-m_{10}\left(T-t_{1}\right)-m_{11} \log \left(\frac{1+R-T}{1+R-t_{1}}\right)
\end{array}\right\}\right. \\
& +\left\{\frac{b c}{2} T^{2}+n_{1} T+n_{2} \log (1+R-T)\right\} \times \\
& \left.\left\{\frac{(1+R)}{2}\left(T^{2}-t_{1}^{2}\right)-\frac{R_{1}}{3}\left(T^{3}-t_{1}^{3}\right)+\frac{c}{4}\left(T^{4}-t_{1}^{4}\right)\right\}\right]
\end{aligned}
$$

3) The deterioration cost (DC) is

$$
D C=C_{d} \int_{t_{1}}^{T} \theta(t) I_{2}(t) d t
$$




$$
C_{d}\left[\begin{array}{l}
u_{3}\left(T^{3}-t_{1}^{3}\right)+\frac{n_{1}}{2}\left(T^{2}-t_{1}^{2}\right) \\
-\frac{b c^{2}}{8}\left(T^{4}-t_{1}^{4}\right) \\
\left.\left.\quad \begin{array}{l}
\frac{c}{2}\left(T^{2}-t_{1}^{2}\right)+\left(\frac{2 T-c T^{2}}{2}\right) \log (1+R-T) \\
n_{2} \\
-\left(\frac{2 t_{1}-c t_{1}^{2}}{2}\right) \log \left(1+R-t_{1}\right) \\
-u_{1}\left(T-t_{1}\right)+u_{2} \log \left(\frac{1+R-T}{1+R-t_{t}}\right)
\end{array}\right)\right\} \times \\
+\left\{\frac{b c}{2} T^{2}+n_{1} T+n_{2} \log (1+R-T)\right\} \times \\
\left\{\left(T-t_{1}\right)-\frac{c}{2}\left(T^{2}-t_{1}^{2}\right)\right\}
\end{array}\right]
$$

4) The purchasing cost (PC) is $C P=C_{p} \times Q$

$$
=C_{p}\left(\begin{array}{l}
n_{3}\left(1-e^{c_{1}}\right)-\frac{b}{c} t_{1} e^{c_{1}} \\
+\left\{\frac{b c}{2}\left(t_{1}^{2}-T^{2}\right)+n_{1}\left(t_{1}-T\right)+n_{2} \log \frac{\left(1+R-t_{1}\right)}{1+R-T}\right\}\left(1+R-t_{1}\right)
\end{array}\right)
$$

5) The sales revenue cost (SRC) is

$$
S R C=p \int_{0}^{T} D(t) d t
$$

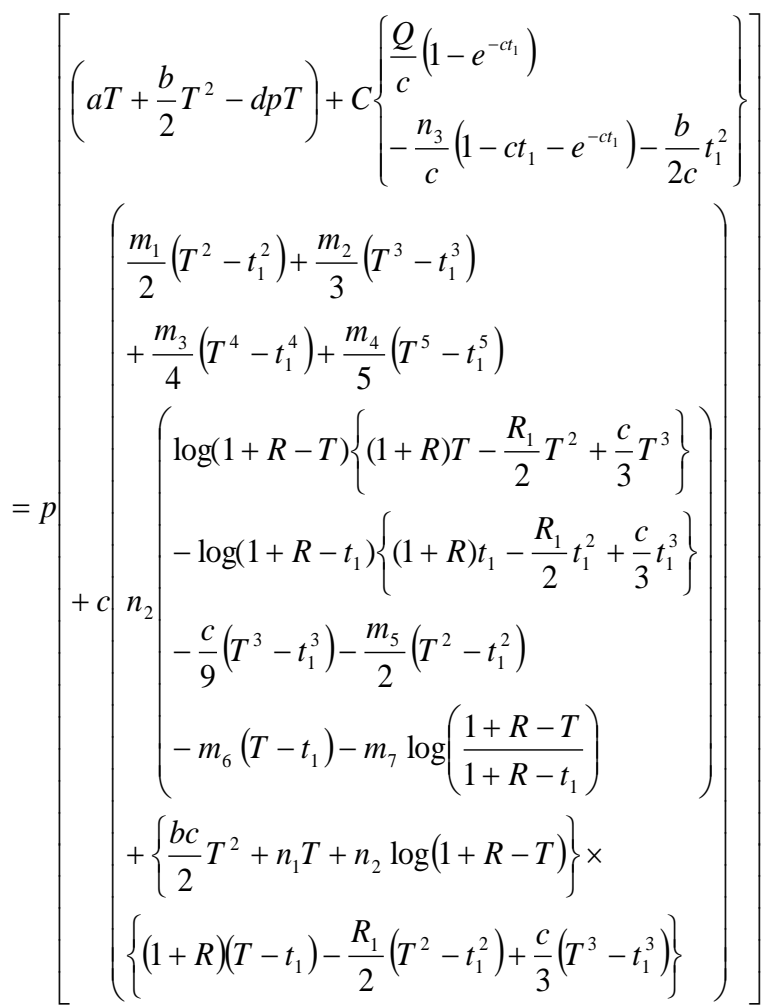

Total profit TPF per unit time is

$$
T P F=\frac{1}{T}\left[C S R-C O-C H-C D-C P-I P_{1}+I E_{1}\right]
$$

The total profit TPF is maximum if

$$
\begin{aligned}
& \frac{d T P F}{d t_{2}}=0 \\
& \frac{d^{2} T P F}{d t_{2}^{2}}<0
\end{aligned}
$$

\section{NUMERICAL EXAMPLE}

To illustrate the inventory model, following data is used on the basis of previous study: $\mathrm{a}=45, \mathrm{~b}=0.8, \mathrm{c}=0.2, \mathrm{~d}=0.6, \mathrm{R}=10, \mathrm{t} 1=2$, $\mathrm{A}=80, \mathrm{Cp}=30, \mathrm{~h} 1=3.5, \mathrm{~h} 2=0.6, \mathrm{Cd}=1.7$. Then, the optimal solution is $\mathrm{T}^{*}=9.735, \mathrm{p}^{*}=77.052, \mathrm{TP}^{*}=169.0455$.

\section{CONCLUSION}

This paper proposed an inventory model for non-instantaneous deteriorating items with price and stock dependent demand rate. Numerical example has been provided in this proposed inventory model to illustrate the results. This model is very helpful to vehicle showrooms and shopping malls etc. For future research, this inventory model can be extended in several ways, shortages, variable holding cost, stochastic demand rate, production dependent model, partial backlogging, inflation, permissible delay in payment, two warehouses etc.

\section{ACKNOWLEDGMENTS}

The authors would like to thank the Editor-in-chief of the journal and Reviewer for their support and beneficial comments to improvement of the paper. The authors would like to express their heartiest gratitude to Dr. P.S. Bhatnagar, Director, B.K. Birla Institute of Engineering \& Technology Pilani, Rajasthan (India).

\section{REFERENCES}

[1] Levin, R.I., McLaughlin, C.P., Lamone, R.P., and Kottas, J.F., 1972. Productions/Operations Management: Contemporary Policy for Managing Operating Systems, McGraw-Hill, New York, p. 373.

[2] Gupta, R., Vrat, P., 1986. Inventory model with multiitems under constraint systems for stock dependent consumption rate. Operations Research 24, 41-42.

[3] Baker, R.C., Urban, T.L., 1988. A deterministic inventory system with an inventory-level-dependent demand rate. Journal of the Operational Research Society 39, 823-831.

[4] Mandal, B.N., Phaujdar, S., 1989. An inventory model for deteriorating items and stock-dependent consumption rate. Journal of the Operational Research Society 40, 483-488.

[5] Datta, T.K., and Pal, A.K., 1990. "A note on an inventory model with inventory level dependent demand rate", Journal of the Operational Research Society, 41, 971-975.

[6] Pal, S., Goswami, A., Chaudhuri, K.S., 1993. A deterministic inventory model for deteriorating items with stock-dependent demand rate. International Journal of Production Economics 32, 291-299.

[7] Bar-Lev, S.K., Parlar, M., and Perry, D., 1994. "On the EOQ model with inventory-level-dependent demand rate and random yield", Operations Research Letters, 16, 167176 
[8] Padmanabhan, G., and Vrat, P., 1995. "EOQ models for perishable items under stock dependent selling rate", European Journal of Operational Research, 86, 281-292.

[9] Giri, B.C., Pal, S., Goswami, A., Chaudhuri, K.S., 1996. An inventory model for deteriorating items with stockdependent demand rate. European Journal of Operational Research 95, 604-610.

[10] Urban, T.L., and Baker, R.C., 1997. "Optimal ordering and pricing policies in a single-period environment with multivariate demand and markdowns", European Journal of Operational Research, 103, 573-583.

[11] Giri, B.C., and Chaudhuri, K.S., 1998. "Deterministic models of perishable inventory with stock dependent demand rate and nonlinear holding cost", European Journal of Operational Research, 105, 467-474.

[12] Ray, J., Goswami, A., Chaudhuri, K.S., 1998. On an inventory model with two levels of storage and stockdependent demand rate. International Journal of Systems Science 29, 249-254.

[13] Datta, T.K., and Paul, K., 2001. "An inventory system with stock-dependent, price-sensitive demand rate", Production Planning and Control, 12, 13-20.

[14] Chang, C.-T., 2004. "Inventory model with stockdependent demand and nonlinear holding costs for deteriorating items", Asia-Pacific Journal of Operational Research, 21, 435-446.

[15] Dye, C.Y., Ouyang, L.Y., 2005. An EOQ model for perishable items under stock dependent selling rate and time-dependent partial backlogging. European Journal of Operational Research 163, 776-783.

[16] Alfares, H.K., 2007. Inventory model with stock-level dependent demand rate and variable holding cost. International Journal of Production Economics 108, 259265 .

[17] Soni H, Shah N. H., 2008. Optimal ordering policy for stock-dependent demand under progressive payment scheme. European Journal of Operational Research, 184:91-10.

[18] Goyal, S.K., Chang, C.-T., 2009. Optimal ordering and transfer policy for an inventory with stock dependent demand. European Journal of Operational Research 196, $177-185$.

[19] Sana, S.S., 2010. An EOQ model for perishable item with stock-dependent demand and price discount rate. American Journal of Mathematical and Management Sciences American Journal of Mathematical and Management Sciences, Vol. 30(3-4), 299-316.

[20] Chang, C.T., Teng, J.T. and Goyal, S.K., 2010. Optimal replenishment policies for non-instantaneous deteriorating items with stock-dependent demand, International Journal of Production Economics, Volume 123, 62-68.

[21] Singh, S. R., Malik, A. K. and Gupta, S. K., 2011. Two Warehouses Inventory Model with Partial Backordering and Multi-Variate Demand under Inflation, International Journal of Operations Research and Optimization, Vol. 2, No. 2, 371-384.

[22] Singh, S. R., Malik, A. K. and Gupta, S. K., 2011. Two Warehouses Inventory Model for Non-Instantaneous Deteriorating Items With Stock-Dependent Demand,
International Transactions in Applied Sciences, Vol. 3, No. $4,749-760$.

[23] Malik, A. K. and Kumar, Sanjay 2011. Two Warehouses Inventory Model with Multi-Variate Demand Replenishment Cycles and Inflation, International Journal of Physical Sciences, Vol. 23, No. 3, 847-854.

[24] Sana, S.S., 2011. An EOQ model for salesmen's initiatives, stock and price sensitive demand of similar products - a dynamical system. Applied Mathematics and Computation $218,3277-3288$

[25] Singh, S. R. and Malik, A. K. 2011.An Inventory Model with Stock-Dependent Demand with Two Storages Capacity for Non-Instantaneous Deteriorating Items, International Journal of Mathematical Sciences and Applications, Vol. 1, No. 3, 1255-1259.

[26] Malik, A. K. and Sharma, Ashu 2011. An Inventory Model for Deteriorating Items with Multi-Variate Demand and Partial Backlogging Under Inflation, International Journal of Mathematical Sciences, Vol. 10, No. 3-4, 315-321.

[27] Sarkar, B., 2012. An EOQ model with delay in payments and stock dependent demand in the presence of imperfect production. Applied Mathematics and Computation, 218, $8295-8308$

[28] Sarkar, B. and Sarkar, S., 2013. An iimproved inventory model with partial backlogging, time varying deterioration and stock-dependent demand, Vol. 30, 924-932.

[29] Sharma, A., Gupta, K. K. and Malik, A.K., 2013. NonInstantaneous Deterioration Inventory Model with Inflation and Stock-Dependent Demand. International Journal of Computer Applications, 67(25), 6-9.

[30] Gupta, K.K., Sharma, A., Singh, P.R. and Malik, A.K., 2013. Optimal Ordering Policy for Stock-Dependent Demand Inventory Model with Non-Instantaneous Deteriorating Items. International Journal of Soft Computing and Engineering 3(1), 279-281.

\section{APPENDIX}

$$
\begin{aligned}
& n_{1}=b+(a-b-d p) c, n_{2}=a-d p+(1+R) n_{1}, \\
& n_{3}=\frac{(a-d p) c-b}{c^{2}}, m_{1}=n_{1}(1+R), \\
& m_{2}=\frac{b c(1+R)-2 n_{1} R_{1}}{2}, m_{3}=\frac{2 n_{1} c-b c R_{1}}{2}, \\
& m_{4}=\frac{b c^{2}}{2}, m_{5}=\frac{c(1+R)}{3}-\frac{R_{1}}{2}, \\
& m_{6}=\left(m_{5}+1\right)(1+R), m_{7}=m_{6}(1+R), \\
& m_{8}=\frac{c(1+R)}{4}-\frac{R_{1}}{3}, m_{9}=\left(m_{8}-\frac{1}{2}\right)(1+R), \\
& m_{10}=m_{9}(1+R), m_{11}=m_{10}(1+R), \\
& u_{1}=\frac{(1+R) c+2}{2}, u_{2}=u_{1}(1+R), \\
& u_{3}=\frac{b c-2 n_{1} c}{6}, R_{1}=(1+R) c+1 .
\end{aligned}
$$




\section{AUTHOR PROFILE}

Mr. Vikram Vashisth is pursuing B. Tech in Computer Science Engineering at B. K. Birla Institute of Engineering \&Technology, Pilani (Rajasthan). His area of interest is Optimizations techniques, soft computing and Big Data.

Mr. Ajay Tomar is pursuing MCA at B. K. Birla Institute of Engineering \& Technology, Pilani (Rajasthan). His area of interest is Optimizations techniques and Soft computing.

Mr. Ramakant Soni, Assistant Professor of Computer Science in B. K. Birla Institute of Engineering \& Technology, Pilani (Rajasthan), has experience of Five years in academics and research. His area of interest is Image processing, Optimizations techniques and Soft computing. He visited EISTI Cergy, France as a visiting Faculty.

Dr. A. K. Malik, Associate Professor of Mathematics in B. K. Birla Institute of Engineering \& Technology, Pilani (Rajasthan), has experience of ten years in academics and research. His area of interest is Inventory control, Soft computing and Supply Chain Management. He has published more than thirty research papers in reputed national and international. $\mathrm{He}$ is reviewer/editorial board member of many national and international journals like as "OPSEARCH" etc. He visited EISTI Cergy, France as a visiting Faculty of Operations Research. 